\title{
PREIMPLANTATION STAGES FROM YOUNG AND SENESCENT GOLDEN HAMSTERS: PRESENCE OF SUCCINIC DEHYDROGENASE AND NON-VIABLE OVA
}

\author{
T. A. PARKENING AND A. L. SODERWALL \\ Department of Biology, University of Oregon, \\ Eugene, Oregon 97403, U.S.A.
}

(Received 30th April 1973)

One of the characteristics of senescence in the female golden hamster is a sudden decline in the production of offspring. This occurs after 14 months of age and was originally believed to result from increased fetal resorption (Soderwall, Kent, Turbyfill \& Britenbaker, 1960). Later studies showed that, although fetal resorption was a factor (Blaha, 1964a; Thorneycroft \& Soderwall, 1969), the major loss occurred before $5 \frac{1}{2}$ days of pregnancy (Connors, Thorpe \& Soderwall, 1972). Although no difference exists in the ovulation rate of young and senescent animals as determined by counting corpora lutea (Thorneycroft \& Soderwall, 1969; Connors et al., 1972), nothing is known about the viability of ova from senescent hamsters before implantation.

Energy metabolism increases considerably during blastocyst formation in the laboratory mouse and rabbit. The increase in $\mathrm{O}_{2}$ consumption during this stage in the mouse is apparently associated with an increased activity in the Krebs' cycle (Brinster, 1971). In the rabbit, this occurs through an alteration in metabolic pathways; tubal embryos use the pentose phosphate shunt and early blastocysts utilize the Embden-Meyerhof pathway and Krebs' cycle (Fridhandler, 1961). If early embryos from senescent animals should fail to alter their metabolic pathways or if faulty enzyme systems exist, this could result in preimplantation loss. This study was conducted to determine whether succinic dehydrogenase was histochemically similar in preimplantation stages of young and senescent golden hamsters.

Young virgin hamsters ( 3 to 5 months of age) and senescent multiparous hamsters (14 to 17 months of age), judged by vaginal discharge to have cycled 3 to 5 times before use, were mated with young males ( 3 to 6 months of age) of proven fertility. Stages were timed from the onset of ovulation, which was considered to be $8 \mathrm{hr}$ from the beginning of behavioural oestrus (Harvey,

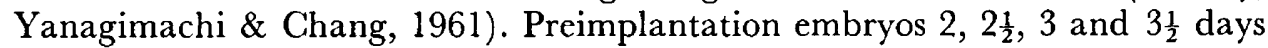
of age were obtained by either mincing oviducts or flushing uterine horns. Succinic dehydrogenase was demonstrated histochemically using Nitro-blue tetrazolium salt (NBT) according to the method of Ishida \& Chang (1965). The formazans formed as blue granules with this salt are known to coincide with the distribution and activity of the mitochondria. All stages were incubated 
for $1 \frac{1}{2} \mathrm{hr}$ at $37^{\circ} \mathrm{C}$ in the substrate solution. Controls were incubated without succinate or pretreated in $10^{-2} \mathrm{M}$-iodoacetate for $30 \mathrm{~min}$ before incubation.

Although some variation existed in the intensity of succinic dehydrogenase, as demonstrated by NBT, among preimplantation stages of young and senescent hamsters at the same time of pregnancy (Table 1), little difference in intensity occurred when observing stages of comparable development (3-day young versus $3 \frac{1}{2}$-day senescent). The total percentage of blastocysts from young $(50.7 \%)$ and senescent $(58.1 \%)$ animals exhibiting a strong NBT reaction was less than that $(78.0 \%)$ described by Ishida \& Chang (1965), in spite of a longer incubation period. This difference may be attributed to the methods of evaluating the intensity of the NBT reaction, or it may be a result of the purity of the NBT salt. It did not appear as if the Krebs' cycle was impaired in the embryos of ageing hamsters as demonstrated histochemically by the presence of succinic dehydrogenase.

Embryos from senescent hamsters exhibited an approximate 12-hr delay in their development and transport through the oviduct when compared with young hamsters (Table 2). All embryos from young animals at $2 \frac{1}{2}$ days of pregnancy were within the uterine horns, predominantly in the nine- to twelve-cell stage, whereas embryos from senescent hamsters remained in the oviducts with several in the four-cell stage and most at the five- to eight-cell stage. In two senescent animals at 3 days of pregnancy, six blastocysts were still present within the oviducts. There was no physical obstruction preventing transport of these blastocysts, as others were recovered from the uterine horns. In young animals at $3 \frac{1}{2}$ days of pregnancy, blastocysts had already lost their zonae pellucidae and many could not be flushed intact from the uterus; this time period was therefore disregarded. All of the blastocysts flushed from senescent hamsters at $3 \frac{1}{2}$ days still retained their zonae pellucidae, and many did not exhibit the prominent blastocyst cavity which was present in all

\section{EXPLANATION OF PLATE 1}

Ova mounted uncompressed were photographed with differential interference contrast microscopy (Nomarski optics). Relative activity for succinic dehydrogenase is given in parentheses after each legend. $\times 420$.

Fig. 1. Two-cell embryo from a senescent hamster at 2 days of pregnancy (moderate).

FIC. 2. Four-cell embryo from a young hamster at 2 days of pregnancy (weak).

FIG. 3. Four-cell embryo from a $2 \frac{1}{2}$-day pregnant senescent hamster (strong).

FiG. 4. Eight-cell embryo from a senescent hamster at $2 \frac{1}{2}$ days of pregnancy (strong).

Fig. 5. Twelve-cell embryo from a $2 \frac{1}{2}$-day pregnant young hamster (strong).

Fig. 6. Blastocyst from a young hamster at 3 days of pregnancy (strong).

Fic. 7. Degenerating ovum from a senescent hamster at 3 days of pregnancy (no treatment).

FIc. 8. $\Lambda$ bnormal embryo from a $3 \frac{1}{2}$-day pregnant senescent hamster (partial activity).

Fic. 9. Two embryos from the same sencscent hamster at 3 days of pregnancy (upperweak, lower-strong). Compare the development of these embryos with the young animal at $2 \frac{1}{2}$ days (Fig. 5).

Fig. 10. Blastocyst from a $3 \frac{1}{2}$-day pregnant senescent hamster (strong).

Fic. 11. Blastocyst from a young hamster at 3 days of pregnancy (moderate). This blastocyst was developmentally more advanced than the majority of blastocysts at this age, as is evident by the thinning of the zona pellucida. 
PLATE 1

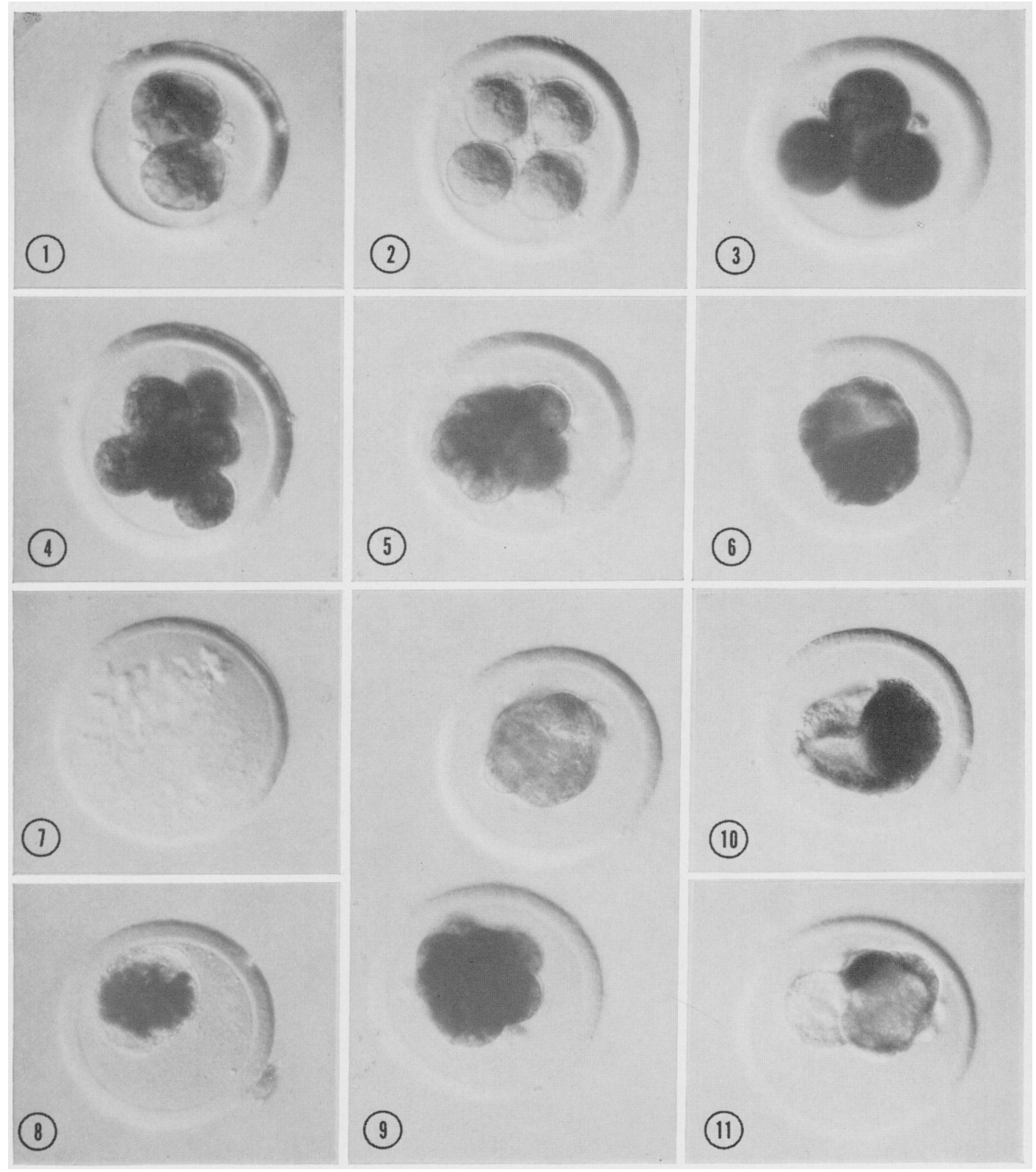

(Facing p. 374) 


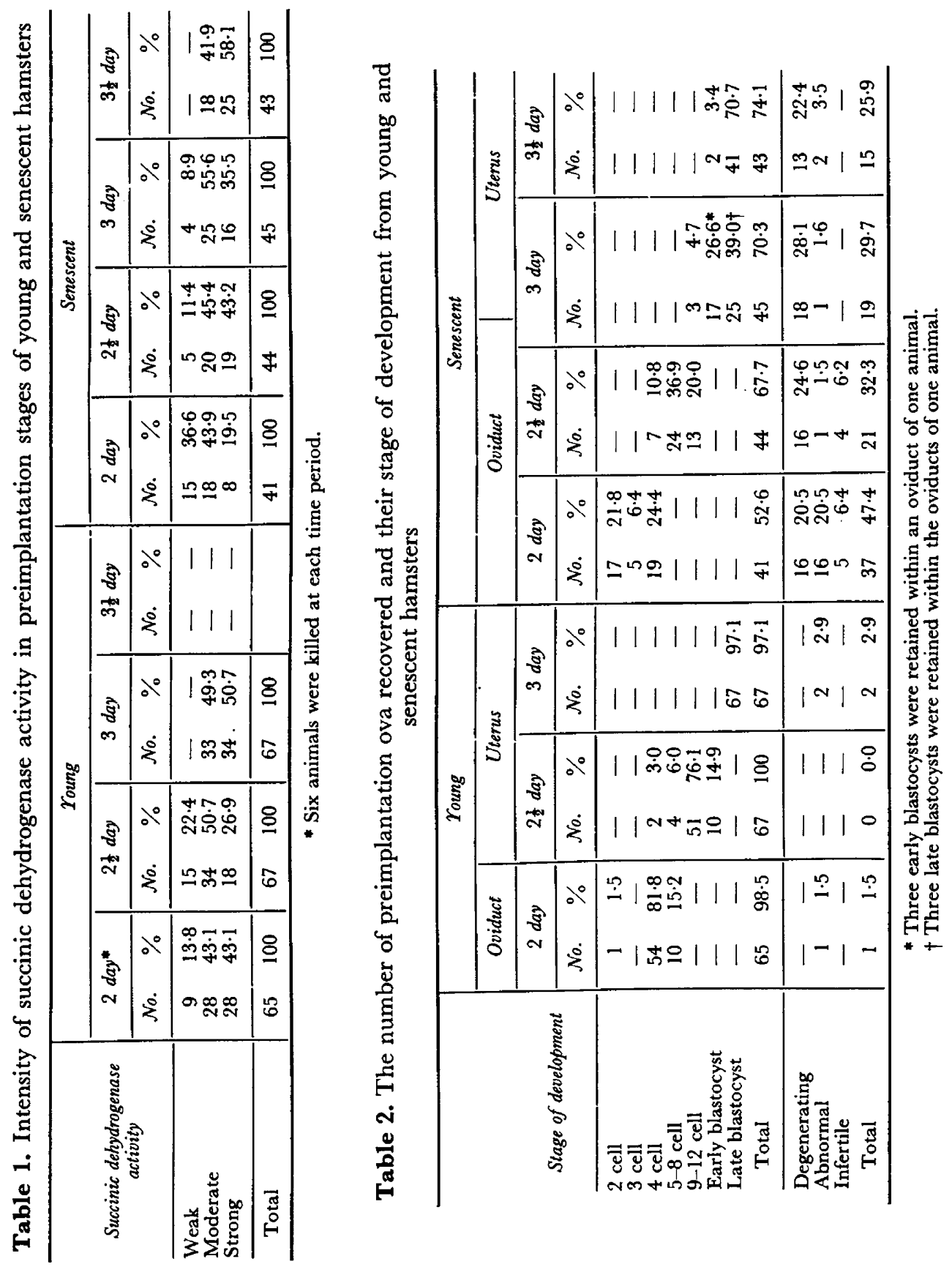


blastocysts from younger animals (3-day pregnant) flushed just before implantation (Plate 1).

Early embryos reported to be developmentally retarded have been described in transplantation studies using these senescent animals: mice (Talbert \& Krohn, 1966), rabbits (Adams, 1970) and hamsters (Blaha, 1964b). In the latter study, Blaha reported that one-sixth of the ova flushed from uterine horns at 63 to $68 \mathrm{hr}$ after ovulation were still in the one-to four-cell stage. $\mathrm{He}$ considered those in the one-cell stage to be unfertilized and those at the four-cell stage to be fertilized but retarded. No data were given regarding degenerating ova though the mean number of ova from twenty-four senescent hamsters at 14 to 18 months of age was 5.08 compared with 9.95 ova from twenty-one young hamsters at $2 \frac{1}{2}$ to 6 months of age.

The large number of infertile, abnormal and degenerating ova found in senescent hamsters in the present study accounted for $47.4 \%$ to $25.9 \%$ of the total ova recovered (Table 2). The decreasing percentage of non-viable ova with an increasing stage of pregnancy was probably due to ovum deterioration, since the total number of ova recovered dropped from seventy-eight on Day 2 to fifty-eight on Day $3 \frac{1}{2}$. Although there was little difference between the average number of ova from eighteen young animals and from twenty-four senescent animals ( 11.22 versus 11.04 ova/animal), non-viable ova from senescent animals accounted for a mean decrease of 3.86 ova/animal. The causes for such a large number of defective ova in older animals is not understood, but preimplantation loss appears to be an important factor in the litter decline noted in senescent golden hamsters.

This research was supported in part by Grant No. HD-04234-03 from the United States Public Health Service.

\section{REFERENCES}

Adams, C. E. (1970) Ageing and reproduction in the female mammal with particular reference to the rabbit. 7. Reprod. Fert. Suppl. 12, 1.

Blaha, G. C. (1964a) Reproductive senescence in the female golden hamster. Anat. Rec. 150, 405.

BLAнA, G. C. (1964b) Effect of age of the dono and recipient on the development of transferred golden hamster ova. Anat. Rec. 150, 413.

BRINster. R. L. (1971) Mammalian embryo metabolism. In: The Biology of the Blastocyst. Ed. R. J. Blandau. University of Chicago Press.

Connors, T. J., ThORPE, L. W. \& Soderwall, A. L. (1972) An analysis of preimplantation embryonic death in senescent golden hamsters. Biol. Reprod. 6, 131.

Fridhandler, L. (1961) Pathways of glucose metabolism in fertilized rabbit ova at various preimplantation stages. Expl Cell Res. 22, 303.

Harvey, E. B., Yanagimachi, R. \& Chiang, M. C. (1961) Onset of estrus and ovulation in the golden hamster. F. exp. Zool. 146, 231.

IshidA, K. \& Chanc, M. C. (1965) Histochemical demonstration of succinic dehydrogenase in hamster and rabbit eggs. 7. Histochem. Cytochem. 13, 470.

Soderwall, A. L., Kent, H. A., Turbyfill, C. I. \& Britenbaker, A. L. (1960) Variation in gestation length and litter size of the golden hamster, Mesocricetus auratus. F. Geront. 15, 246.

TAlbert, G. B. \& Krohn, P. L. (1966) Effect of maternal age on viability of ova and uterine support of pregnancy in mice. . Reprod. Fert. 11, 399.

Thorneycroft, I. H. \& Soderwall, A. L. (1969) The nature of the litter size loss in senescent hamsters. Anat. Rec. 165, 343. 